\title{
Sistem Monitoring Tumbuh Kembang Balita/Batita di Tengah Covid-19 Berbasis Mobile
}

\author{
Styawati $^{1}$, Fenty Ariany ${ }^{2}$ \\ ${ }^{1,2}$ Universitas Teknokrat Indonesia, Fakultas Teknik dan Ilmu Komputer, Jln H Zainal Abidin \\ Pagar Alam 9-11 Labuan ratu , Bandar Lampung, Indonesia, 35132 \\ e-mail: 1'styawati@teknokrat.ac.id, fenty@ teknokrat.ac.id
}

Submitted Date: September $24^{\text {th }}, 2020$

Revised Date: January 02 ${ }^{\text {nd }}, 2021$

\author{
Reviewed Date: December $30^{\text {th }}, 2020$ \\ Accepted Date: January $04^{\text {th }}, 2021$
}

\begin{abstract}
The Corona virus is growing rapidly throughout the world, including in Indonesia. The development of the virus causes many activities related to humans to be stopped first. One of the activities that is not allowed is Posyandu (Pos Pelayanan Terpadu), even though posyandu is very important to do. Due to the importance of the posyandu, the posyandu cadres conduct a mobile posyandu (sweeping). The problem that arises from sweeping is that people who have toddlers are not at home. Even though they are at home, they usually don't want to meet with posyandu cadres because they are afraid of the spread of the Corona Virus. Technological developments can help prevent the spread of the Corona Virus to humans. Any activity related to other people can be done online. In this study, trying to design a system that can monitor the growth of toddlers without having to meet directly with posyandu cadres. The system design is also expected to help Poskeskel (Pos Kesehatan Kelurahan) and Puskesmas (Pusat Kesehatan Masyarakat) to view and print weighing reports without having to ask for monthly weighing data reports for toddlers to Posyandu in Bandar Lampung. In addition, this system is expected to make it easier for posyandu cadres to report every posyandu activity and to report the growth and development of toddlers who are registered at the Flamboyan 9 Posyandu.
\end{abstract}

Keywords: Corona virus; Covid-19; Posyandu; Toddler growth; Technology

\section{Abstrak}

Virus Corona berkembang pesat di seluruh dunia, termasuk juga di Indonesia. Perkembangan virus tersebut menyebabkan banyak aktivitas yang berhubungan dengan sesama manusia dihentikan terlebih dahulu. Salah satu kegiatan yang tidak diperbolehkan adalah Posyandu (Pos Pelayanan Terpadu), padahal posyandu sangat penting dilakukan. Dikarenakan pentingnya posyandu maka para kader posyandu mengadakan posyandu keliling (sweeping). Permasalahan yang timbul dari sweeping adalah warga yang memiliki balita/batita tidak ada di rumah. Meskipun mereka ada di rumah biasanya mereka tidak mau bertemu dengan para kader posyandu dikarenakan takut dengan penyebaran Virus Corona. Perkembangan Teknologi dapat membantu menghambat penyebaran Virus Corona pada manusia. Setiap kegiatan yang berhubungan dengan orang lain dapat dilakukan secara online. Pada penelitian ini mencoba merancang suatu sistem yang dapat memantau pertumbuhan balita/batita tanpa harus bertemu langsung dengan para kader posyandu. Pada rancangan sistem ini juga diharapkan dapat membantu Poskeskel (Pos Kesehatan Kelurahan) dan Puskesmas (Pusat Kesehatan Masyarakat) untuk melihat dan mencetak laporan penimbangan tanpa harus meminta laporan data penimbangan balita/batita setiap bulannya ke posyanduposyandu yang ada di Bandar Lampung. Selain itu, sistem ini diharapkan dapat mempermudah para kader posyandu dalam melaporkan setiap kegiatan posyandu dan melaporkan tumbuh kembang balita/batita yang terdaftar pada posyandu Flamboyan 9.

Keywords: Virus Corona; Covid-19; Posyandu; Pertumbuhan balita/batita; Teknologi 


\section{Pendahuluan}

Penyebaran Corona Virus Disease 2019 (Covid-19) masih masuk dalam kategori tinggi yaitu kasus Covid-19 mencapai angka 19.936.210 kasus dengan 732.499 kematian (CFR 3,7\%) di 215 negara terjangkit dan 171 negara transmisi lokal sesuai dengan data yang diambil dari World Health Organization (WHO) dan Public Health Emergency Operating Center (PHEOC) Kementerian Kesehatan tanggal 11 Agustus 2020. Penyebaran Covid-19 yang begitu cepat memaksa setiap masyarakat untuk dapat membatasi aktivitasnya. Hal ini dilakukan untuk menghambat penyebaran dan menekan jumlah orang yang terinfeksi Covid-19. Penularan Covid-19 dari manusia ke manusia telah terjadi sejak pertengahan Desember 2019. Penyebaran lebih lanjut terus berlangsung dengan cepat selama bulan-bulan berikutnya. Para peneliti memperkirakan bahwa angka reproduksi untuk SARS-CoV-2 adalah 2,2, yang berarti bahwa setiap orang yang terinfeksi dapat menginfeksi rata-rata 2,2 orang. Dalam penelitian lain, jumlah reproduksi SARS-CoV-2 adalah 2,68 dengan waktu penggandaan epidemi 6,4 hari (Sriarumtias et al., 2020).

Pandemi Corona Virus Disease 2019 (Covid-19) masih belum berakhir, meskipun demikian kegiatan posyandu harus tetap dilakukan, hal ini merupakan salah satu kegiatan yang sangat penting untuk mengetahui pertumbuhan dan perkembangan balita/batita. Dampak dari pandemi Covid-19 salah satunya adalah tidak optimalnya pemantauan terhadap kesehatan ibu dan anak. Hal ini disebabkan karena kurangnya layanan kesehatan pada masa pandemi. Tercatat hanya $19,2 \%$ layanan seperti posyandu yang tetap buka selama pandemi (Has, 2020). Penurunan layanan kesehatan seperti posyandu dapat berdampak buruk terhadap tumbuh kembang balita/batita, karena tidak ada pemantauan secara rutin tumbuh kembang mereka. Pemantauan secara rutin perkembangan balita/batita dan pemberian imunisasi serta pemberian vitamin dapat menghindari resiko Stunting pada balita/batita. Stunting atau Balita Kerdil merupakan suatu kondisi kekurangan gizi yang bersifat kronis atau berlangsung dalam waktu yang lama dan ditunjukkan dengan hasil pengukuran tinggi badan menurut umur yang kurang dari 2SD berdasarkan standar pertumbuhan yang dikeluarkan oleh Organisasi Kesehatan Dunia (WHO). Resiko kematian anak yang terkena stunting adalah empat kali lebih besar daripada anak yang beratnya di atas 2SD. Janin dalam kandungan dan anak berusia dua tahun pertama mempunyai risiko untuk mengalami stunting, sehingga menghambat pertumbuhan linier dan perkembangan otak yang berlangsung sangat pesat pada periode tersebut (Efriza Wiwin, 2020). Posyandu sangat dibutuhkan untuk peningkatan kesehatan masyarakat khususnya balita dan bayi. Tidak hanya memberikan pelayanan kesehatan seperti imunisasi, kegiatan Posyandu ini juga mencakup kegiatan administasi seperti pencatatan berat dan tinggi bayi yang tertera pada kartu sehat atau yang terdaftar pada Posyandu tersebut, serta dapat melakukan kegiatan pencatatan aktivitas lainnya seperti konsultasi kesehatan bayi (Savitri \& Nurwasito, 2018). Pemerintah telah mencanangkan kegiatan menuju Indonesia sehat 2010 yang dituangkan pada peraturan menteri dalam negeri nomor 32.2011 yaitu kualitas dan kuantitas dari pembangunan kesehatan sangat ditentukan oleh keberhasilan petugas kesehatan dan kader posyandu dalam memberikan layanan kesehatan kepada masyarakat.

Teknologi yang semakin berkembang khususnya teknologi informasi dan komputer, membuat banyak perusahaan yang menggunakan sistem informasi berbasis computer untuk mendukung kelancaran kegiatan operasi perusahaan tidak terkecuali pemerintahan(Suryono et al., 2018). Selain teknologi di bidang sistem informasi, teknologi internet juga sangat dibutuhkan untuk memberikan kemudahan dalam menerima dan mengakses informasi dalam berbagai format dari seluruh penjuru dunia (Putra \& Suryono, 2009). Salah satu sektor pemerintah yang membutuhkan sistem mobile adalah Posyandu.

Kegiatan posyandu dapat dilakukan dengan menggunakan teknologi berbasis online dalam setiap aktivitas yang berhubungan dengan orang lain, Hal ini dilakukan untuk mengurangi penyebaran Covid-19. Pemanfaatan teknologi mobile salah satu solusi yang dapat digunakan (Rahmanto \& Utama, 2018)(Najib et al., 2020). Para kader posyandu dan petugas kesehatan tetap bisa menjalankan tugasnya dengan bantuan aplikasi online berbasis mobile. Terdapat banyak keunggulan dari penggunaan platform mobile android diantaranya yaitu mudah dibawa dan dapat diakses dimana saja dan kapan saja (Rulyana \& Borman, 2015). Pemahaman kader terkait kegiatan posyandu akan berpengaruh terhadap kemampuan para kader dalam 
mengaktifkan kegiatan posyandu, sehingga akan mempengaruhi terlaksananya program kerja posyandu. Perilaku para kader dalam bertugas di posyandu yang didasari pengetahuan akan lebih langgeng dari pada perilaku yang tidak didasari oleh pengetahuan (Notoatmodjo, 2003). Informasi mengenai kesehatan dan perkembangan pertumbuhan balita/batita sangat penting, karena anak dengan status gizi yang baik dan sehat dapat lebih aktif merespon semua perubahan yang ada di lingkungan. (Khomsan, 2006).

\section{Metode Penelitian}

Penelitian ini dilakukan di posyandu Flamboyan 9 Kotabaru Tanjungkarng Timur Bandar Lampung, dimana berdasarkan hasil observasi terdapat 50 balita/batita peserta posyandu.

Tahapan penelitian yang dilakukan dapat dilihat pada Gambar 1

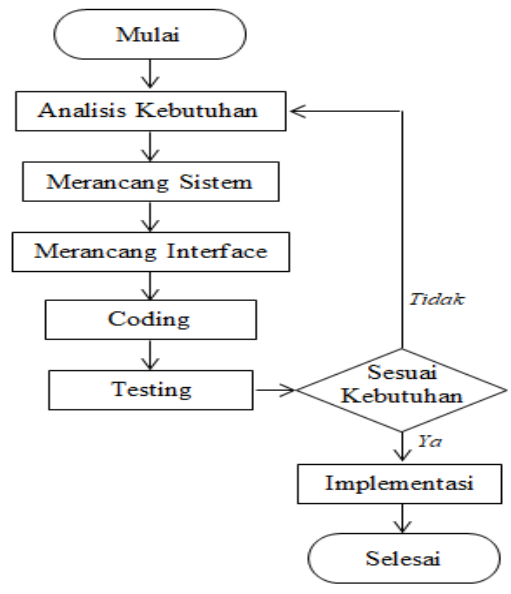

Gambar 1 Tahapan Penelitian

\section{a) Analisis Kebutuhan}

Pada proses ini dimulai dengan melakukan observasi ke lapangan. Observasi dilakukan di posyandu flamboyan 9 kotabaru tanjungkarang timur bandar lampung. Data hasil observasi yang dilakukan dapat dilihat pada Gambar 1 dan Gambar 2.

Tabel 1 Data Penimbangan Bulan Januari

\begin{tabular}{|c|c|c|c|}
\hline \multirow{2}{*}{ Keterangan } & \multicolumn{2}{|c|}{ Jenis Kelamin } & \multirow{2}{*}{ Total } \\
\cline { 2 - 3 } & Laki Laki & Perempuan & \\
\hline 0 - 5 Bulan & 0 & 3 & 3 \\
\hline 6 - 11 Bulan & 3 & 1 & 4 \\
\hline 12 - 24 Bulan & 9 & 8 & 17 \\
\hline 25 - 56 Bulan & 12 & 16 & 22 \\
\hline Total & 24 & 26 & 50 \\
\hline
\end{tabular}

Tabel 2 Data Penimbangan Bulan Februari

\begin{tabular}{|c|c|c|c|}
\hline \multirow{2}{*}{ Keterangan } & \multicolumn{2}{|c|}{ Jenis Kelamin } & \multirow{2}{*}{ Total } \\
\cline { 2 - 3 } & Laki Laki & Perempuan & \\
\hline 0 - 5 Bulan & 0 & 3 & 3 \\
\hline 6 - 11 Bulan & 3 & 1 & 4 \\
\hline 12 - 24 Bulan & 9 & 8 & 17 \\
\hline 25 - 56 Bulan & 12 & 16 & 22 \\
\hline Total & 24 & 26 & 50 \\
\hline
\end{tabular}

Pelaksanaan penimbangan balita/batita disetiap posyandu dilakukan satu bulan sekali dengan jam tayang dari jam 08.00 - 12.00 WIB. Petugas posyandu atau kader posyandu terdiri dari 5 orang kader, 2 orang tim dari puskesmas. Setiap selesai tayang posyandu, maka kader akan membuatkan laporan perkembangan balita/batita para peserta posyandu. Laporan tersebut untuk mengetahui dan mengontrol keadaan para balita/batita baik dari segi gizinya maupun perkembangan tubuh si bayi.

\section{b) Rancangan Sistem}

Rancangan sistem yang dibangun memiliki 3 aktor/pengguna yaitu: kader posyandu, peserta posyandu (orangtua balita/batita) dan petugas puskesmas. Rancangan tersebut dapat dilihat pada Gambar 2

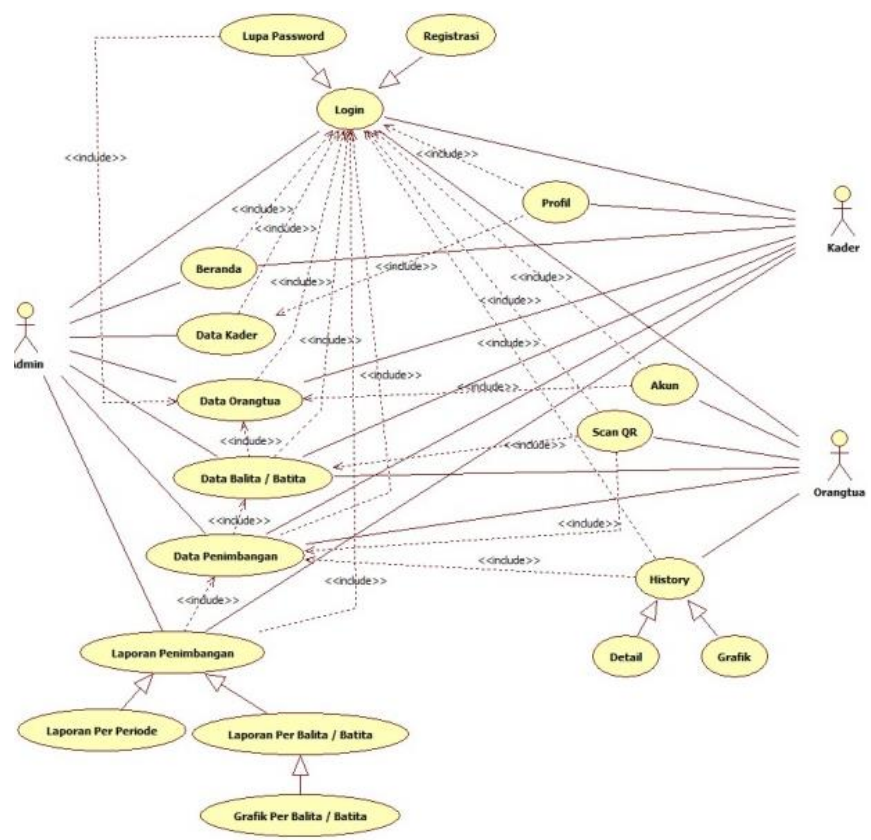

Gambar 2 Use Case Diagram

1. Orangtua balita/batita.

Orangtua balita/batita dapat dengan mudah mengetahui pertumbuhan dan perkembangan balita/batitanya dimanapun dan kapanpun orangtua balita/batita berada. Informasi tumbuh 
kembang balita/batita yang diberikan oleh sistem berdasarkan pada masukan yang diberikan oleh orang tua yaitu berat badan dan tinggi badan balita/batitanya.

2. Kader Posyandu

Setiap kader dapat melaksanakan semua tugas yang ada pada saat posyandu. Kader dapat melakukan registrasi pendaftar, mencatat hasil penimbangan, melakukan penimbangan dan dapat melihat informasi terkait tumbuh kembang balita/batita yang terdaftar di posyandu Flamboyan 9 Kotabaru Tanjungkarang Timur Bandar Lampung.

3. Puskesmas / admin

Report atau laporan yang dibutuhkan oleh petugas puskesmas dapat diperoleh dengan mudah, kapanpun dan dimanapun petugas puskes membutuhkan.

\section{Hasil dan Pembahasan}

Aplikasi digunakan untuk mempercepat proses pendaftaran peserta posyandu, mempermudah orang tua dalam mencari informasi tumbuh kembang balita/batitanya, mempermudah para kader posyandu dalam melaporkan setiap kegiatan posyandu dan melaporkan tumbuh kembang balita/batita yang terdaftar pada posyandu Flamboyan 9. Adapun cara menggunakan aplikasi tersebut yakni terdapat tiga menu login (login kader, login puskesmas dan login orang tua). Berikut tampilan rancangan sistem yang diusulkan.

\section{A. Form Login}

Untuk menjaga keamanan sistem monitoring tumbuh kembang balita/batita ini dirancang dengan sistem keamanan berupa login. Form login pada sistem ini digunakan untuk akses orangtua, petugas puskesmas dan kader posyandu dalam mengakses sistem.

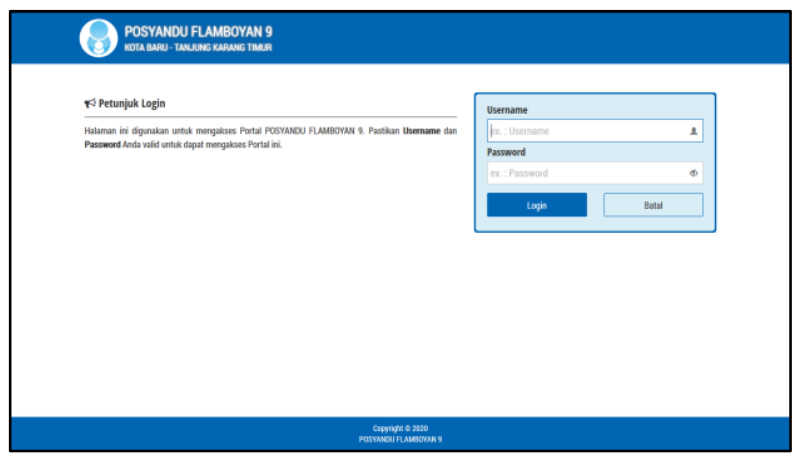

Gambar 3 Form Login

\section{B. Form Beranda}

Form beranda digunakan untuk menampilkan overview data-data yang terkait. Data pada beranda seperti data admin, data kader, data orangtua, data balita/batita, data penimbangan, dan data laporan penimbangan. Form beranda dapat dilihat pada gambar 4 .

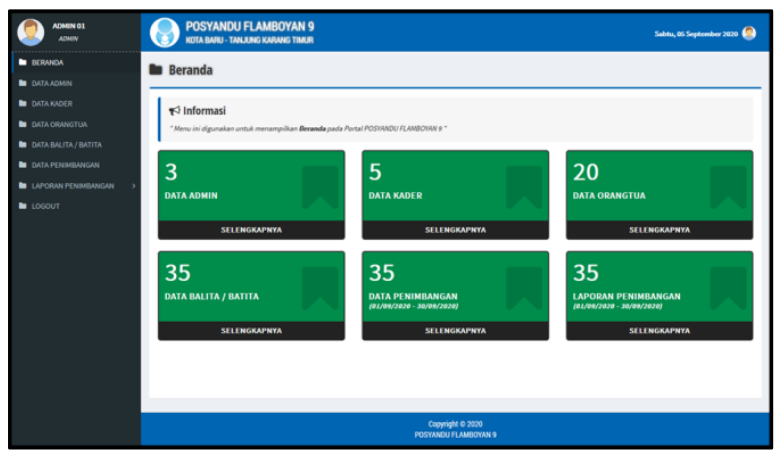

Gambar 4 Form Beranda

\section{Form Data Admin}

Form data admin digunakan untuk menampilkan data admin. Admin pada sistem ini adalah petugas puskesmas. Form data admin dapat dilihat pada gambar 5 .

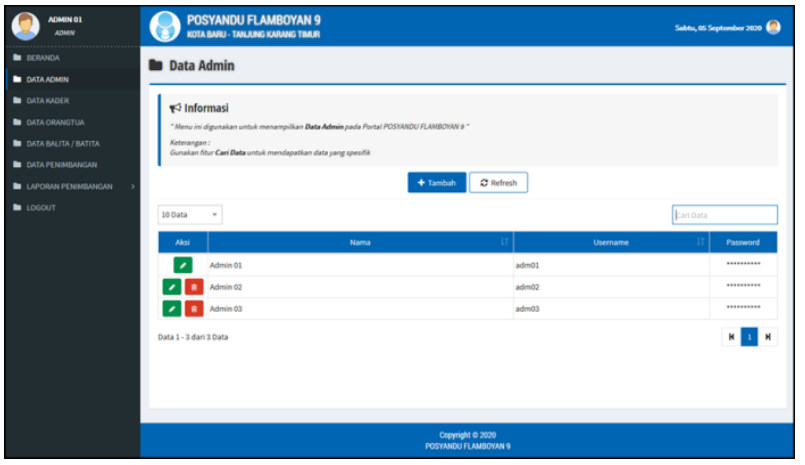

Gambar 5 Form Data Admin

\section{Form Data Kader}

Form data kader digunakan untuk menampilkan data kader posyandu. Data kader posyandu hanya dapat ditambah dan dirubah oleh admin. Form data kader dapat dilihat pada gambar 6. 


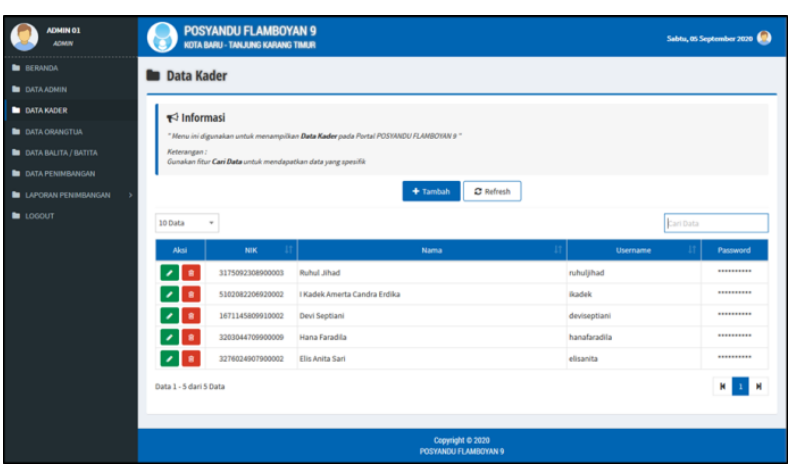

Gambar 6 Form Data Kader

\section{E. Form Data Orangtua}

Form data orangtua digunakan untuk menampilkan data orangtua balita/batita. Data orangtua sangat berhubungan dengan data anak, maka pada saat registrasi harus mengunggah kartu keluarga yang di dalamnya terdapat nama balita/batita. Form data orangtua dapat dilihat pada gambar 7 .

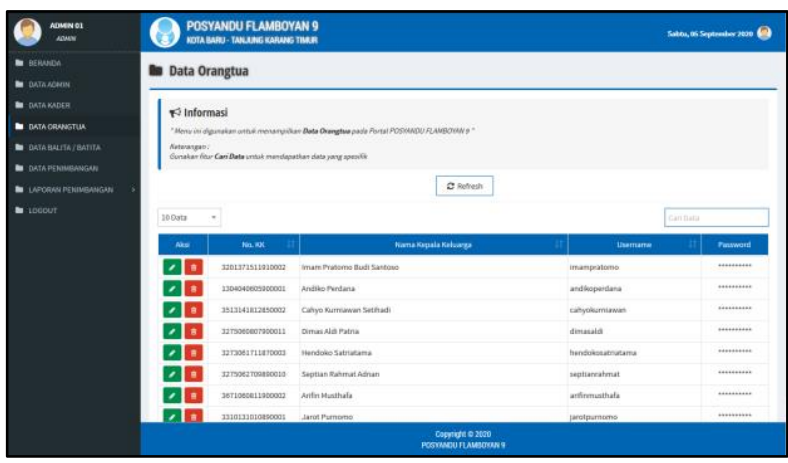

Gambar 7 Form Data Orangtua

\section{F. Form Data Balita/Batita}

Form data balita/batita digunakan untuk menampilkan data balita/batita. Data balita/batita akan ditampilkan setelah data orangtua dan data balita/batita ditambahkan ke sistem. Form balita/batita dapat dilihat pada gambar 8 .

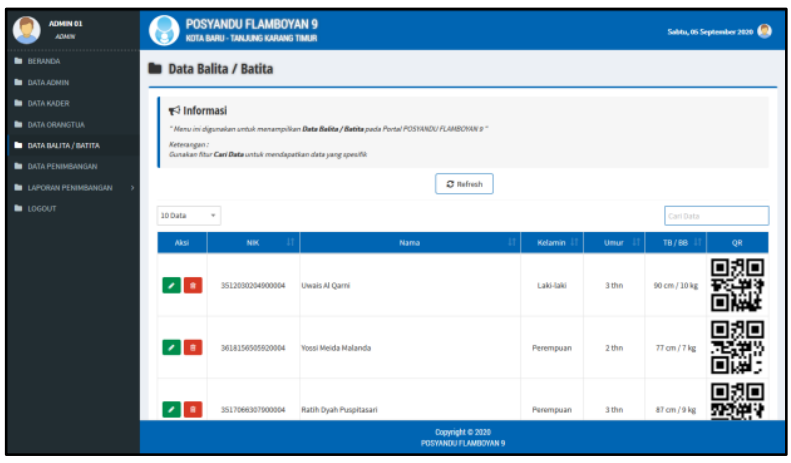

Gambar 8 Form Data Balita/Batita
G. Form Ubah Data Balita/Batita

Form ubah data balita/batita digunakan untuk mengubah data balita/batita. Jika terdapat kesalahan dalam memasukkan data balita/batita maka data tersebut dapat diubah menggunakan form ini. Form ubah data balita/batita dapat dilihat pada gambar 9.

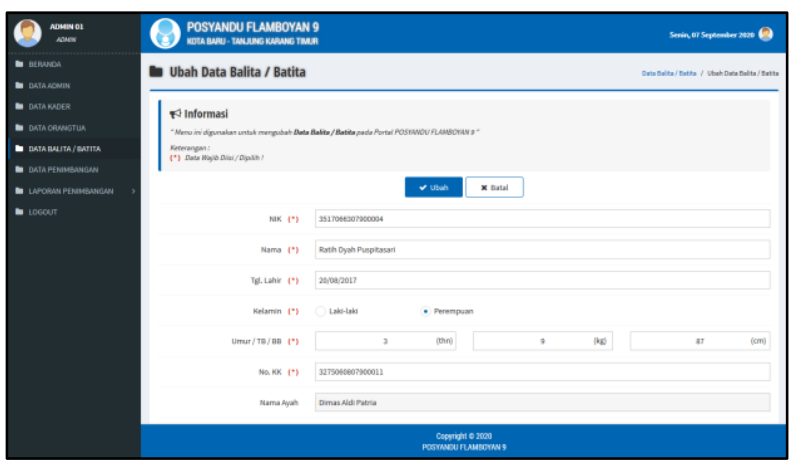

Gambar 9 Form Ubah Data Balita/Batita

H. Form QR Code Data Balita/Batita

Form QR Code Data Balita/Batita digunakan untuk scan data QR code balita/batita sebelum melakukan penimbangan. Scan QR pada sistem ini digunakan untuk mempermudah para kader dalam mengakses sistem monitoring tumbuh kembang balita/batita. Form scan QR dapat dilihat pada gambar 10.

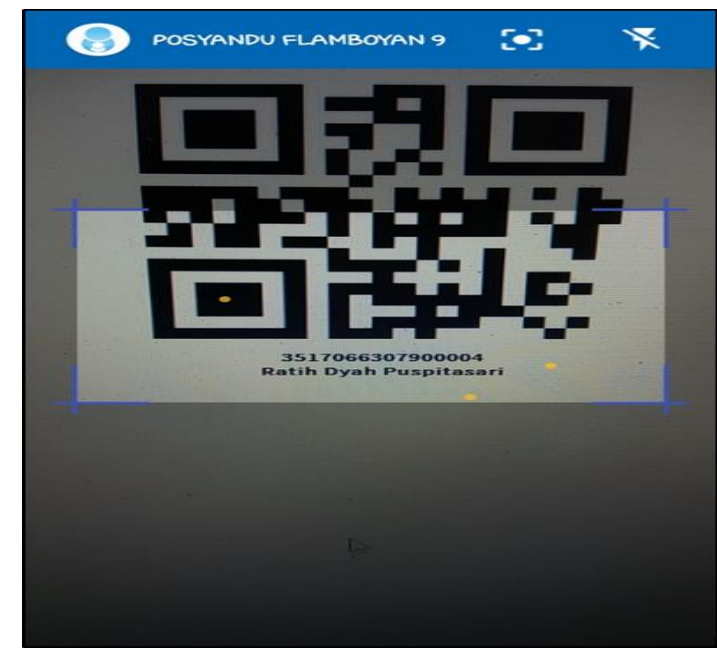

Gambar 10 Form QR Code Data Balita/Batita

I. Form Hasil Scan QR

Form hasil scan QR digunakan untuk menampilkan data balita/batita hasil scan QR code dan memasukan data hasil penimbangan serta data pengukuran tinggi badan. Form hasil scan QR dapat dilihat pada gambar 11. 


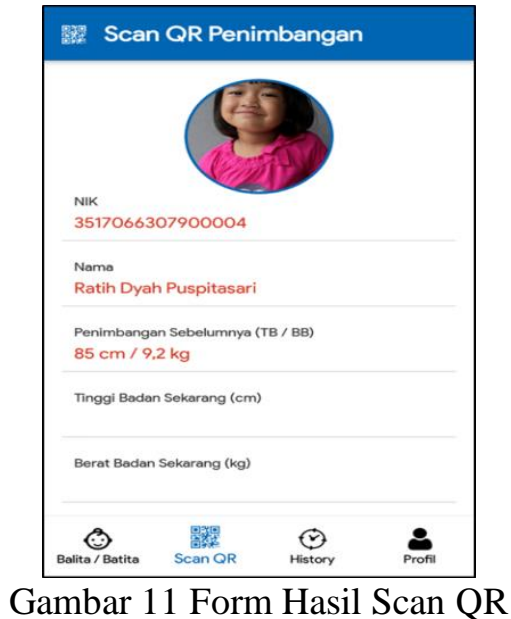

J. Form Data Penimbangan

Form data penimbangan digunakan untuk menampilkan data penimbangan balita/batita. Data penimbangan balita/batita difungsikan untuk mengetahui status gizi balita/batita. Form data penimbangan dapat dilihat pada gambar 12 .

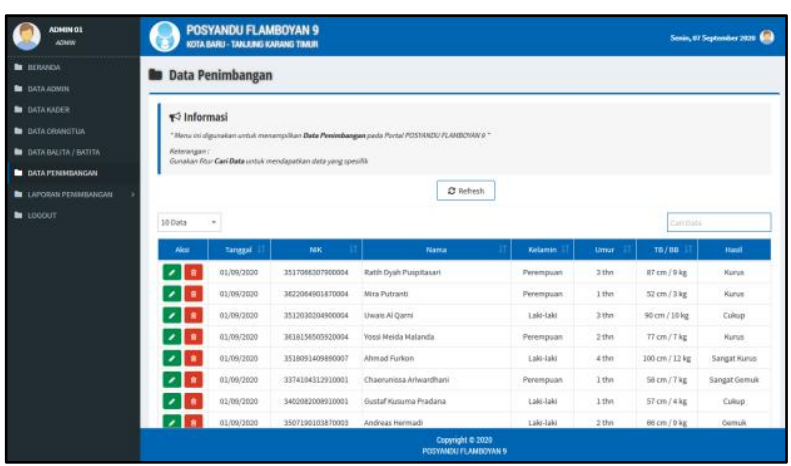

Gambar 12 Form Data Penimbangan

\section{K. Form Ubah Data Penimbangan}

Form ubah data penimbangan digunakan untuk mengubah data penimbangan balita/batita. Jika terdapat kesalahan dalam memasukkan berat badan dan tinggi badan maka dapat melakukan perubahan data melalui form ini. Form ubah data penimbangan dapat dilihat pada gambar 13 .

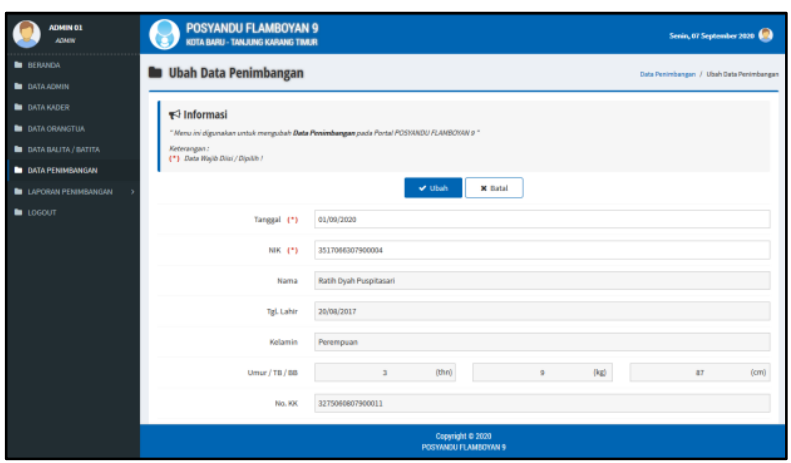

Gambar 13 Form Ubah Data Penimbangan
L. Form Laporan Penimbangan (per periode)

Form laporan penimbangan per periode digunakan untuk menampilkan data penimbangan balita/batita berdasarkan periode yang dipilih. Periode yang digunakan adalah tanggal,bulan dan tahun. Form laporan penimbangan per periode dapat dilihat pada gambar 14 .

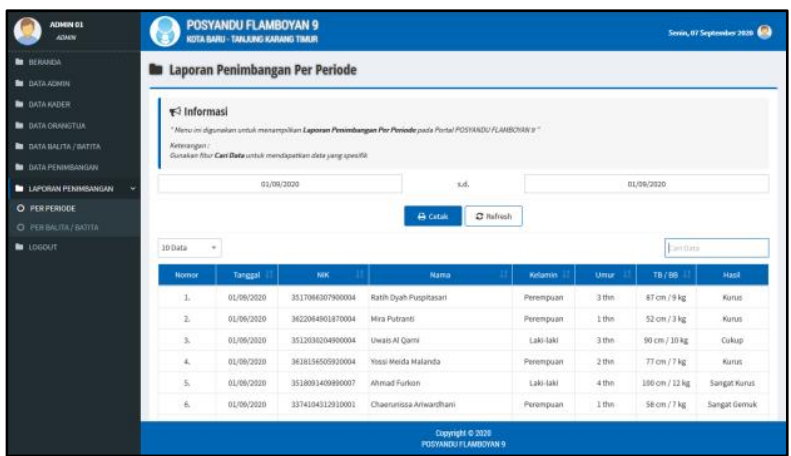

Gambar 14 Form Laporan Penimbangan per periode

M. Form Cetak Laporan Penimbangan (per periode)

Form cetak laporan penimbangan per periode digunakan untuk mencetak laporan penimbangan balita/batita berdasarkan periode yang dipilih. Form cetak laporan penimbangan perperiode dapat dilihat pada gambar 15 .

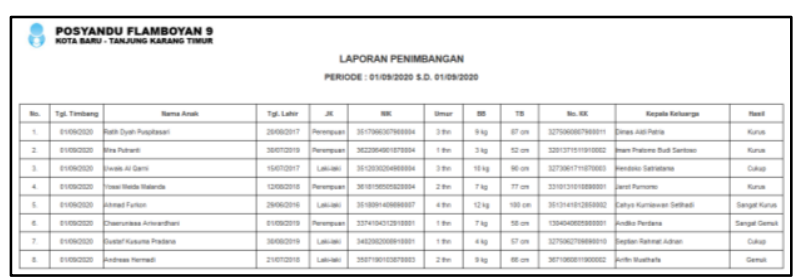

Gambar 15 Form Cetak Laporan Penimbangan (per periode)

N. Form Laporan Penimbangan (per balita/batita) Form laporan penimbangan (per balita/batita) digunakan untuk menampilkan history data penimbangan setiap balita/batita. Form laporan penimbangan (per balita/batita) dapat dilihat pada gambar 16. 


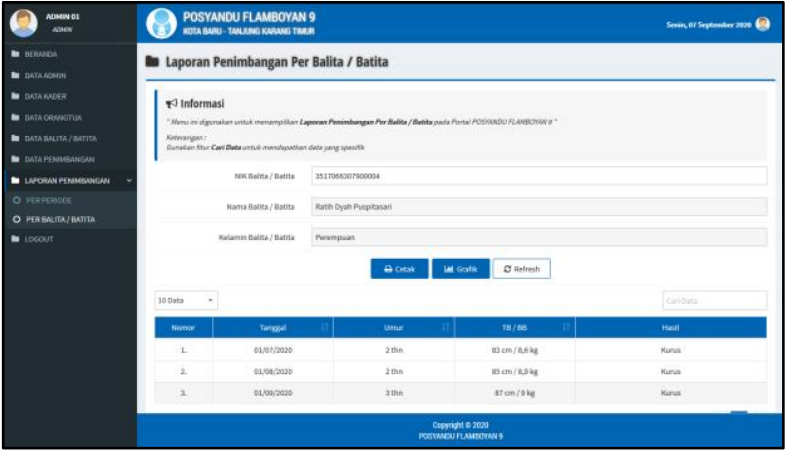

Gambar 16 Form Laporan Penimbangan (per balita/batita)

O. Form Cetak Laporan Penimbangan (per balita/batita)

Form cetak laporan penimbangan (per balita/batita) digunakan untuk mencetak laporan history data penimbangan setiap balita/batita. Form laporan penimbangan (per balita/batita) dapat dilihat pada gambar 17.

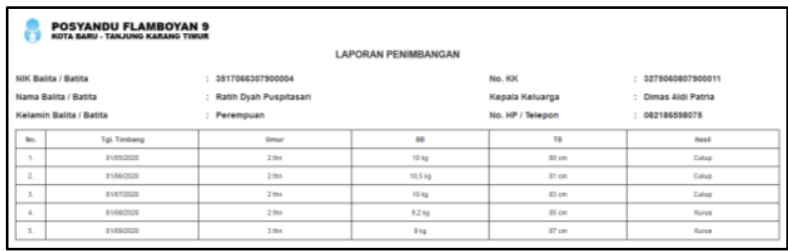

Gambar 17 Form Cetak Laporan Penimbangan (per balita/batita)

P. Form Grafik Penimbangan (per balita/batita)

Form grafik penimbangan digunakan untuk mencetak grafik history data penimbangan setiap balita/batita. Form grafik penimbangan dapat dilihat pada gambar 18 .

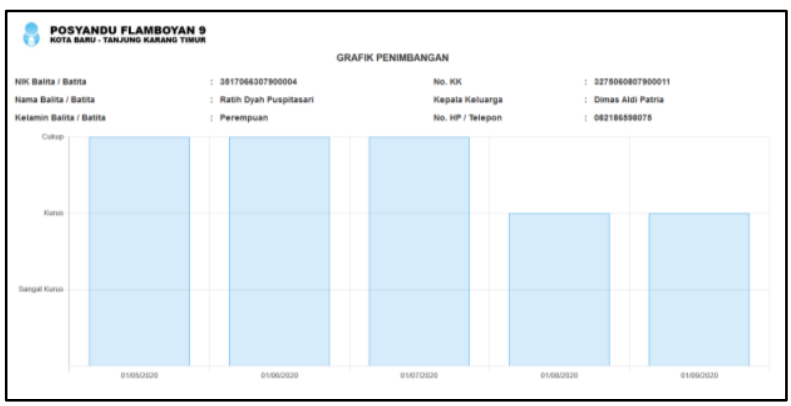

Gambar 18 Form Grafik Penimbangan (per balita/batita)

\section{Kesimpulan}

Berdasarkan analisis, bahwa rancangan aplikasi sistem ini dapat membantu orangtua, kader posyandu dan puskesmas untuk memonitoring tumbuh kembang balita/batita di tengah-tengah situasi pandemi Covid-19. Para kader, orangtua dan puskesmas dapat tetap menjalankan aktivitasnya dalam melakukan penimbangan balita/batita walaupun dalam situasi pandemi Covid-19. Penelitian selanjutnya dapat dilakukan proses klasifikasi untuk mengetahui kepuasan masyarakat terhadap layanan posyandu. Proses klasifikasi dapat menggunakan metode Support Vector Machine-Firefly Algorithm (SVM-FA). SVM-FA memiliki akurasi lebih tinggi dibandingkan SVM(Styawati \& Mustofa, 2019).

\section{Ucapan Terima Kasih}

Terima kasih kami ucapkan kepada Universitas Teknokrat Indonesia yang telah memberikan dana hibah Penelitian Pembinaan Kapasitas (PPK) tahun pelaksanaan 2020, sehingga kami dapat merancang suatu sistem yang bisa membatu masyarakat dalam memecahkan permasalahan menganai monitoring pertumbuhan dan perkembangan balita/batita di situasi pandemi COVID saat ini.

\section{Referensi}

Efriza Wiwin. (2020). Berdampakkah pandemi covid-19 terhadap stunting di bangka belitung? 09(03), 154-157.

Has, E. M. M. (2020). Tunaikan Layanan Kesehatan Ibu dan Anak di Masa Pandemi Covid-19. 5.

Khomsan, A. (2006). Sehat dengan Makanan Berkhasiat.

Najib, M., Satria, D., Saputra, F., Pasha, D., Informasi, S., Indonesia, U. T., \& Indonesia, U. T. (2020). Mit App Invertor Pada Aplikasi Score Board untuk Pertandingan Olahraga Berbasis Android. 14(2), 81-88.

Notoatmodjo, S. (2003). Pendidikan dan perilaku kesehatan. Rineka Cipta.

Peraturan Menteri Dalam Negeri Nomor 32, (2011).

Putra, A. D., \& Suryono, R. R. (2009). Rancang Bangun Media Pembelajaran TOEFL berbasis Web. 2009(Snati), 73.

Rahmanto, Y., \& Utama, R. Y. (2018). Penerapan Teknologi Web3D Berbasis Android Sebagai Media Pembelajaran Gerakan Dasar Silat. Jurnal TAM (Technology Acceptance Model), 9(1), 7-14. http://ojs.stmikpringsewu.ac.id/index.php/Jur nalTam/article/view/593

Rulyana, D., \& Borman, R. I. (2015). Aplikasi Tes Potensi Akademik Berbasis Mobile Platform Android. Jurnal Teknik Dan Sistem 
Informatika, $\quad 11(1), \quad 1-11$. http://ejurnal.teknokrat.ac.id/index.php/tekno info/article/view/85/85

Savitri, N., \& Nurwasito, H. (2018). Pengembangan Aplikasi Mobile untuk Pelayanan Administrasi Posyandu dengan menggunakan Google Maps Api Geolocation Tagging. Jurnal Pengembangan Teknologi Informasi Dan Ilmu Komputer, 2(No.1 Januari 2018), 63-72.

Sriarumtias, F. F., Andeani, R. F., Rosita, N., \& Ardian, F. (2020). Pemberdayaan serta Penerapan Protokol Kesehatan di Posyandu Puskesmas Leuwigoong Kabupaten Garut, Jawa Barat Sebagai Upaya Mencegah Penularan COVID-19. JUPIKAT (Jurnal Pengabdian Kepada Masyarakat), 1(1), 112.

Styawati, S., \& Mustofa, K. (2019). A Support Vector Machine-Firefly Algorithm for Movie Opinion Data Classification. IJCCS (Indonesian Journal of Computing and Cybernetics Systems), 13(3), 219. https://doi.org/10.22146/ijccs.41302

Suryono, R. R., Darwis, D., \& Gunawan, S. I. (2018). Audit Tata Kelola Teknologi Informasi Menggunakan Framework Cobit 5 (Studi Kasus: Balai Besar Perikanan Budidaya Laut Lampung). Jurnal Teknoinfo, 12(1), https://doi.org/10.33365/jti.v12i1.38 